\title{
Effect of Credit Management Policy on Financial Performance of Listed Consumer Goods Companies in Nigeria
}

\author{
Akporien Fidelis ${ }^{1} \&$ Nsima Johnson Umoffong ${ }^{2}$ \\ ${ }^{1,2}$ Department of Accounting, Faculty of Business Administration, University of Uyo, Uyo \\ Akwa Ibom State
}

\begin{abstract}
The study examines the effect of credit policy management on financial performance of listed consumer goods companies in Nigeria. The study adopted the ex post facto research design and used content analysis of corporate financial statements to extract relevant data from sampled firms for the period 2016 to 2019. The population of the study consisted of all listed consumer goods companies in Nigeria. Findings of the study indicate that cash conversion cycle has a negative but not significant association with financial performance. The study further revealed that average collection period has a positive and significant association with financial performance while debt equity ratio has a positive but insignificant relationship with financial performance. The study concludes that good credit management policy enhance financial performance of listed consumer goods companies in Nigeria and recommends that companies particularly the consumer goods companies should establish credit management policies that clearly outline the management's view of organization priorities on profitability.

KEYWORDS: Credit Management, Cash Conversion Cycle, Average Collection Period, Debt Ratio, Financial Performance

DOI: $10.7176 /$ RJFA/11-10-17

Publication date:May $31^{\text {st }} 2020$

\section{Introduction}

Credit management is an essential and crucial element in planning, control, decision making and evaluation of business performance. Trade credit is also know a accounts receivables is normally created between a buyer and a seller by which the seller allows delayed payment for its products or services instead of instant cash payment. It has been argued that effective credit management is necessary in an economic system where financial markets are not predictable, contract enforcement is insecure, and information is scarce and unreliable. According to Ifurueze (2013), proper management of credit in manufacturing firms is of high importance and cannot be over emphasized due to its ability to affect financial performance, existence and the entire growth and sustainability of the firms. As dynamics of corporate organisations change, companies are using trade credit as a prominent strategy in the area of financial management and marketing. Corporate managers have come to realize that trade credits are necessary in the growth and survival of the businesses. Trade credits create accounts receivables which the firm is expected to collect in future. Accounts receivables which are executed through issuing of credit invoices are one of the largest assets of a business enterprise comprising approximately $15 \%$ to $20 \%$ of the total assets of a typical manufacturing corncern (Dunn, 2009). Onuora and Ifeacho (2017) explain that investment in receivables takes a big chunk of organization's total assets and further posit that these type of current assets are highly vulnerable to bad debts and losses hence the need to manage accounts receivables as a component of working capital appropriately.
\end{abstract}

Credit management policy significantly differs among corporate organizations. However, no matter how large or small an organization is and regardless of the differences in their operations or product, the effects of credit policies usually bring about similar consequences (Otuya \& Eginiwin, 2017). Effects of a credit policy are either good enough to bring growth and profits or bad enough to bring declination and losses. This similarity is as a result of the aim of every manager which is to collect their receivables efficiently and effectively, thus maximizing their cash inflows (Ojeka, 2012). Thus, this study seeks to examine the effect of credit management policy on the financial performance of the listed consumer goods companies in Nigeria.

\section{Conceptual Review}

\section{Credit Management Policy}

Credit management policy as a guideline is adopted to regulate the terms and conditions for the sale of goods and services on credit basis, customer qualification criteria, procedure for making collections and steps to be taken in case of customer delinquency (Pandey, 2004). Long (1993) further notes that absence of an effective credit management policy to regulate sales made to customers on credit, there could be liquidity problems that can pose a negative effect on firms' growth and survival. Credit management is an essential part in any business 
organization, due to the fact that contemporary business transactions are based on agreed credit terms by both seller and buyers (Otuya \& Akporien, 2017). The fact is, without a proper management of firm's credit components, smooth and effective operation of the firms will be hindered. Thus, according to Brigham \& Houston (2003), it was affirmed that about 60 percent of a typical financial manager's time is devoted in managing the firm's credit affairs and allocations. Thus, an efficient allocation of resources tends to influence favourably the firm profitability and as a result enhanced growth.

Agu and Basil (2013) contend that a good credit management policy reduces the risk of doubtful and bad debts while a poor management of trade debt can lead to the provision of a large sum of funds for doubtful and bad debts and losses (Pandey, 2010).

Thus, credit management policy is designed to minimize costs associated with trade credits or accounts receivables while maximizing the benefits from it. Kalunda, Nduku and Kabiru (2012) assert that credit policy can either be lenient or stringent. They further explain that a lenient credit policy tends to give credit to customers on very liberal terms and standards such that credit is granted for longer periods even to those customers whose credit worthiness is not well known. A stringent credit policy on the other hand is restrictive and allows credit only to those customers whose credit worthiness have been ascertained and are financially strong.

\section{Financial Performance}

Profit is a major way to measure financial performance of a company. Profit is the difference between revenues and expenses over some time usually one year, and it is regarded as the final output of a company's operation. Profit maximization is one of the objectives of any business venture is to maximize profit, which determines the short-term survival (Mbu-Ogar, Effiong \& Abang, 2017). Profit is vital, but management decisions should not only be profit-oriented at the detriment of wealth maximization. A company without sufficient profit would have no future. In this study, financial performance is in terms of return on total assets (Effiong, Akpan \& Oti. 2012). This profitability ratio measures the overall performance of the company by determining the effectiveness and viability of the company in general terms (Pandey, 2010).

Return on Assets (ROA) falls within the domain of performance measures and tracks of a firm ability to generate income based on its assets. ROA is expected to be positive as a reflection of the profit margin of the firm, otherwise it reflects non-profit or loss. Return on assets is an indicator of how profitable a company is relative to its total assets. ROA gives an idea as to how efficient management is at using its assets to generate earnings (Khatab, Masood, Zaman, Saleem, \& Saeed, 2011).

\section{Theoretical Review: Trade-off theory}

Under perfect capital market assumptions, holding cash neither creates nor destroys value. The firm can always raise funds from capital markets when funds are needed, because the capital market is assumed to be fully informed about the prospects of the firm. The trade-off theory explains that firms target an optimal level of liquidity to balance the benefit and cost of holding cash which includes delay in payment to suppliers on one hand and allows company of discounts for prompt or early payment on other hand. These benefits save transaction costs to raise funds and do not need to liquidate assets to make payments and the firm can use liquid assets to finance its activities and investment if other source of funding are not available or are extremely expensive. Considering account receivables, it argued that a flexible trade credit policy with an interest on receivables may increase sales (Deloof \& Jegers, 1996). As theory, the use of trade off model cannot be ignored, as it explains that, firms with high management of accounts receivables should hold an effective credit management technique that balances the tradeoff between liquidity and profitability.

\section{Empirical Review}

Previous empirical studies captured to support this study have come up with divergent results. Washam (2012) examined shareholder returns from supplying trade credit and the study was carried out to examine shareholder wealth implications of supplying financing to customers. The data used was collected from a large sample of US firms between the periods of 1971-2006. A descriptive and regression analysis technique was adopted for the study and the revealed that return and trade received are directly related. Thus, the study established that trade credit as an effective instrument of checking financial frictions hindered sales growth. Akinleye and Olarewanju (2019) examine the effect of credit management on the profitability growth of manufacturing firms in Nigeria from 2007 
to 2016. Panel data regression technique was used. The study reveals that cash conversion cycle and collection period were positively related with the manufacturing firms' growth and a negative relationship was discovered between the payment periods. The study concludes that the non-compliance of the manufacturing firms to credit management had hampered their growth and sustainability; the cash conversion cycle had great influence thereby enhanced the growth of manufacturing firms in Nigeria.

Gul, Khan, Rehman, Khan, Khan and Khan (2013) examined the contribution of credit management on performance of small medium enterprises in Pakistan. The study used regression analysis technique to model the collected data and establish the relationship that exists between credit management and performance of SMEs in Pakistan. The results revealed that number of days account, growth and firm size are directly related with profitability whereas number of days account receivable, number of day's inventory, cash conversion cycle and debit ratio have and inverse relation with profitability.

Mathuva (2010) studied the influence of trade credit on corporate profitability of manufacturing firms in Nairobi. The analysis done using regression showed that a highly significant negative relationship exists between the time taking by the firms to collect cash from their customers and profitability. Omesa, Maniagi, Musiega and Makori (2013) studied the relationships between credit management and corporate performance of manufacturing firms listed on the Nairobi securities exchange using a sample of 20 companies with five years data. A principal components analysis was used due to its simplicity and its capacity of extracting relevant information from confusing data sets. From the results using principal components analysis and multiple regression technique, credit management captured by cash conversion cycle, average collection period and control variables current liabilities, net working capital, turnover ratio and fixed financial ratio were statistically significant in determining the corporate performance of manufacturing firms measured by return on equity. Onuora and Ifeacho (2017) in a study examines the effect of credit management on the profitability of manufacturing firm using five quoted firms in Nigeria stock exchange. The intent of the study was to determine whether credit management mechanism: credit policy, liquidity management and debtors' turnover have effect on profitability of manufacturing firm measured by return on assets (ROA). Data was sourced from annual report of selected companies. The result reveals that credit policy and liquidity management has significant negative relationship to Return on Assets while debtors' turnover has significant positive effect to Return on Assets.

Kungu et al (2014) in a paper considered the effects of credit policy on profitability of manufacturing firms in Kenya. The study looked at the elements that constitute the credit policy; credit terms, collection efforts, credit period and credit standards. A descriptive research design was used to collect the data from the field and a stratified random sampling technique was used to come up with a sample of 81 manufacturing firms. A questionnaire was used to collect data from 81 manufacturing firms in Nairobi industrial area and its environs in Kenya. However, only 71 questionnaires were returned. The chief finance officers of the manufacturing firms were requested to fill in the questionnaire. Both descriptive and inferential analyses were done. Analysis of Variance (ANOVA) and regression analysis were used to test the hypothesis. The results show that there is a positive relationship between profitability and credit policy in the manufacturing firms in Kenya (0.304). Credit policy explains only $9.2 \%$ of the profitability in the manufacturing firms in Kenya. $90.8 \%$ of the variation in profitability is explained by other factors. The findings of the study revealed that the way credit policy is designed impacts on the profitability of manufacturing firms. Therefore, we recommend that the finance managers of manufacturing firms regularly review the credit policy of their firms to ensure that they are ideal and result in increased profitability.

Okpala, Osanebi and Irinyemi (2019) evaluated the impact of credit management strategies on the liquidity and profitability of quoted chemical \& paints manufacturing companies in Nigeria. The descriptive survey research design was implemented. 500 staff representing $60 \%$ of the population was used as the sample population upon which copies of questionnaire were administered. 342 valid responses were returned by the participants and analyzed. One-way ANOVA was used for descriptive statistics, and a simple regression analysis method was used to test the formulated hypotheses. The result obtained indicated that the credit management strategies sub-variables - credit risk assessment, debt recovery strategy, receivable collection policy, have positive and statistically significant impact on the liquidity sub-variable - Ability to pay, level of bad debt, and cash inflow $(\mathrm{R}=.654$ $\mathrm{R} 2=.632, \mathrm{p}=.0<.05 ; \mathrm{R}=.692, \mathrm{R} 2=.674, \mathrm{p}=.0<.05 ; \mathrm{R}=.621, \mathrm{R} 2=.601, \mathrm{p}=.0<.05)$. The effect of liquidity on profitability was positive and statistically significant $(\mathrm{R}=.723, \mathrm{R} 2=.701, \mathrm{p}=.0<.05)$.

Effiong and Ejabu (2020) in a study examine the effect of liquidity risk management on the financial performance of consumer goods companies. It was aimed at establishing the extent of concern of consumer goods companies in the management of their liquid cash, cash defensive intervals, long term debts, and quick ratios, for the purpose of turning around their financial performance. Data were obtained from the annual reports and accounts of studied 
companies and were converted to liquidity measurement parameters. Analyses were done using multiple regression analysis methods and findings show that long term debts, quick ratios, and cash defensive intervals have a significant effect on EPS and ROA, while cash ratio and long term debts affect ROCE only. Specifically, it was empirically established that there exists a significant relationship between liquidity risk management and the financial performance of consumer goods companies .Findings further reveal that companies' non-concerned attitude to liquidity risk management affects the financial performance of consumer goods companies significantly.

\section{Methodology}

\section{Research Design}

The study adopted an ex-post factor research design since the data were already available. The study also used the correlational approach to find the relationship between and among variables.

\section{Population and Sampling}

The population of this study comprises of food and beverages companies listed in the Nigeria Stock Exchange. Of the 304 listed firms, 16 companies are operating in the consumer goods sector. Based on this population, a normal confidence level of $95 \%$ and error tolerance of $0.05 \%$ was used. The final sample size for this study was based on the Yamane's formula (1967). The statistical formula is stated, thus: $n=N / 1+N\left(e^{2}\right)$.

Where $\mathrm{n}=$ Sample size; $\mathrm{N}=$ Population size; $\mathrm{e}=$ level of significance desired.

Given that: $\mathrm{N}=16$ and $\mathrm{e}=0.05$, the sample therefore $=16 / 1+16\left(0.05^{2}\right)$ which gives a sample size of 15 companies.

\section{Methods of Data Collection}

Secondary data were used for the study. The secondary data were retrieved from financial statements and notes in the annual reports of the sampled food and beverages companies. The secondary data were obtained from the financial statements of the sampled listed consumer goods firms from 2016-2019.

\section{Table 1: Operational Measures of Variables}

\begin{tabular}{|c|c|c|c|}
\hline Variables & Measurement & Appriori sign & Notation \\
\hline $\begin{array}{l}\text { Financial } \\
\text { performance }\end{array}$ & $\begin{array}{l}\text { To be measured as PAT (Profit After Tax) } \\
\text { divided by Total Asset. }\end{array}$ & + & $\mathrm{ROA}$ \\
\hline $\begin{array}{l}\text { Cash } \\
\text { Conversion } \\
\text { Cycle }\end{array}$ & $\begin{array}{l}\text { Average collection period + Inventory } \\
\text { Conversion Period - Average Payment } \\
\text { Period }\end{array}$ & - & $\mathrm{CCC}$ \\
\hline $\begin{array}{l}\text { Average } \\
\text { Collection } \\
\text { Period }\end{array}$ & $\begin{array}{l}\text { Average Account Receivable/ } \\
\text { Net Sales x } 365\end{array}$ & + & $\mathrm{ACP}$ \\
\hline $\begin{array}{l}\text { Debt Equity } \\
\text { Ratio }\end{array}$ & $\begin{array}{l}\text { This is measured as total debt divided by total } \\
\text { shareholders' equity }\end{array}$ & + & DER \\
\hline
\end{tabular}

\section{Model Specification}

To test the hypothesis developed, a linear and multivariate regression model which expresses financial performance as a function of credit management policy is stated in functional form as follows:

$\mathrm{ROA}_{\mathrm{it}}=\beta_{0}+\beta_{1} \mathrm{CCC}_{\mathrm{it}}+\beta_{2} \mathrm{ACP}_{\mathrm{it}}+\beta_{3} \mathrm{DER}_{\mathrm{it}}+\mathrm{e}_{\mathrm{it}}$

Where:

ROA $=$ Return on Assets

$\mathrm{CCC}=$ Cash Conversion Cycle 
$\mathrm{ACP}=$ Average Collection Period

DER $=$ Debt Ratio

$\mathrm{e}=$ Stochastic or disturbance term

$\mathrm{i}=$ Companies

$\mathrm{t}=$ Time dimension of the Variables

$\beta_{0}=$ Constant or intercept

$\beta_{1-3}=$ Coefficients to be estimated or the Coefficient of slope parameters.

\section{Method of Data Analysis}

The study adopted use of multivariate regression analysis as the analytical procedure to find the correlation between variables in the study. This will facilitate our understanding of which among the independent variables are related to the dependent variable and to explore the forms of these relationships.

\section{Decision Rule}

At $5 \%$ level of significance if the P-value is less or equal to 0.05 , we reject null hypothesis (Ho). But if the P-value is greater than 0.05 then we accept the null hypothesis.

\section{Presentation of Results and Discussion}

Table 2: Descriptive Statistics

\begin{tabular}{|l|c|c|c|c|}
\hline & ROA & CCC & ACP & DER \\
\hline Mean & 0.229183 & 192.6120 & 35.43272 & 0.277167 \\
\hline Median & 0.215900 & 165.1137 & 34.27995 & 0.220000 \\
\hline Maximum & 0.611700 & 616.4404 & 242.1832 & 0.766000 \\
\hline Minimum & 0.061200 & 102.0850 & 1.399500 & 0.036000 \\
\hline Std. Dev. & 0.121294 & 87.05070 & 37.28712 & 0.182157 \\
\hline Skewness & 0.887209 & 2.226677 & 3.179332 & 1.083350 \\
\hline Kurtosis & 3.867586 & 10.59523 & 17.47475 & 3.371136 \\
\hline Jarque-Bera & 9.753159 & 193.7996 & 624.8774 & 12.08084 \\
\hline Probability & 0.007623 & 0.000000 & 0.000000 & 0.002381 \\
\hline Sum & 13.75100 & 11556.72 & 2125.963 & 16.63000 \\
\hline Sum Sq. Dev. & 0.868015 & 447091.6 & 82029.42 & 1.957690 \\
\hline Observations & $\mathbf{6 0}$ & $\mathbf{6 0}$ & $\mathbf{6 0}$ & $\mathbf{6 0}$ \\
\hline
\end{tabular}

Table 2 shows the descriptive statistics of the variables in the model. The mean for ROA is 0.229 . The highest and lowest level of financial performance is $61.1 \%$ and $6.1 \%$ respectively. The standard deviation of 0.121 indicates a substantial dispersion from the mean. The descriptive statistics also show a mean of 192.612 days for CCC which indicate that it takes an average of 193 days to convert stock to cash in the sampled firms. The standard deviation of 87 is low from the mean and indicates that there is not much variation among the companies surveyed.

Further, ACP and DER are seen to have mean values of 34.432 days 0.277 respectively. The standard deviation also stood at 37 days and 0.182 for ACP and DER respectively also indicating no significant dispersion from their mean values.

\section{Table 3: Correlation Analysis}

\begin{tabular}{|c|r|r|r|r|}
\hline & \multicolumn{1}{|c|}{ ROA } & \multicolumn{1}{c|}{ CCC } & \multicolumn{1}{c|}{ ACP } & \multicolumn{1}{c|}{ DER } \\
\hline ROA & 1.000000 & -0.073887 & 0.175036 & -0.030079 \\
\hline CCC & -0.073887 & 1.000000 & -0.067621 & 0.405316 \\
\hline ACP & 0.175036 & -0.067621 & 1.000000 & -0.115943 \\
\hline DER & -0.030079 & 0.405316 & -0.115943 & 1.000000 \\
\hline
\end{tabular}


A correlation matrix is adopted to check the level of relationship between the dependent and independent variables on one part, and among the independent and control variables on the other.

The correlation statistics shows that ROA has a positive relationship with ACP $(\mathrm{r}=0.175)$, and a negative relationship with CCC $(\mathrm{r}=-0.073)$ and DER $(\mathrm{r}=-0.030)$. The correlation also shows that CCC has a positive relationship with DER ( $\mathrm{r}=0.405)$ and a negative relationship with ACP $(\mathrm{r}=-0.067)$. Finally, ACP is observed to have a negative correlation with DER $(\mathrm{r}=-0.115)$.

\section{Analysis of Findings}

Findings of the study using results of the Panel Data Regression estimates are discussed below:

\section{Table 4: Regression Results}

Dependent Variable: ROA

Method: Pooled Least Squares

Date: 04/11/20 Time: 05:34

Sample: 20162019

Included observations: 60

Cross-sections included: 4

Total pool (balanced) observations: 240

\begin{tabular}{lrlrr}
\hline \hline \multicolumn{1}{c}{ Variable } & Coefficient & Std. Error & t-Statistic & Prob. \\
\hline \hline \multicolumn{1}{c}{ C } & 0.224637 & 0.021560 & 10.41914 & 0.0000 \\
CCC & $-9.69 \mathrm{E}-05$ & $9.75 \mathrm{E}-05$ & -0.994171 & 0.3212 \\
ACP & 0.000561 & 0.000210 & 2.677374 & 0.0079 \\
DER & 0.012059 & 0.046803 & 0.257649 & 0.7969 \\
\hline \hline R-squared & 0.394777 & Mean dependent var & 0.229183 \\
Adjusted R-squared & 0.022507 & S.D. dependent var & 0.120530 \\
S.E. of regression & 0.119166 & Akaike info criterion & -1.400076 \\
Sum squared resid & 3.351313 & Schwarz criterion & -1.342066 \\
Log likelihood & 172.0092 & Hannan-Quinn criter. & -1.376702 \\
F-statistic & 2.834377 & Durbin-Watson stat & 0.683626 \\
Prob(F-statistic) & 0.038933 & & \\
\hline \hline
\end{tabular}

Table 03 shows the summarized regression results. The regression estimates indicate that we can explain $39.4 \%$ of the financial performance using credit policy management as determinants while $60.6 \%$ of the variation is explained by other factors outside the model and the error term. The Prob(F-Statistic) of $2.834(\mathrm{P}<0.05)$ also indicates that credit policy management is a significant determinant of financial performance of consumer goods firms in Nigeria.

As regards individual credit management policy, $\mathrm{CCC}$ is found to have a negative but insignificant association with the financial performance at $5 \%$ significant level $\left(\beta_{1}\right.$ BoCCCit $=0.96 E$, $t$-Statistic $\left.=-0.994\right)$. The result did not meet our appriori expectation. This result is consistent with prior studies (Mathuva, 2010; Akinleye \& Olarewanju, 2019)

In addition, the coefficient of the variable ACP is observed to be positive and significant $\left(\beta_{2} A C P i t=0.00561, t\right.$ Statistic $=0.267$ ). This indicates that the level of profitability of a firm is significantly influenced by average collection period. The result meets our appriori expectation and is consistent with previous studies such as (Okpala, Osanebi \& Irinyemi, 2019)

The regression result on DER variable shows a positive association but not statistically significant at $5 \%$ $\left(\beta_{3}\right.$ DERit $=0.012$, $t$-Statistic $\left.=0.257\right)$. The result also indicates a Prob $(0.796>0.05)$ which gives enough evidence to accept the hypothesis that level of debt to equity is not significantly associated with financial performance. This position meets our appriori expectation and agrees with studies such as (Onuora \& Ifeacho, 2017). 


\section{Conclusion and Recommendations}

The study examines the effect of credit policy management on financial performance of listed consumer goods companies in Nigeria. The study adopted the ex post facto research design and used content analysis of corporate financial statements to extract relevant data from sampled firms for the period 2016 to 2019. The study further deployed some descriptive, correlation and regression analyses to evaluate how the mean outcomes deviate from each other and establish the level of association between variables.

The analysis indicates that cash conversion cycle has a negative but not significant association with financial performance. Findings of the study further reveal that average collection period has a positive and significant association with financial performance. Moreover, the study finds that leverage has a positive but insignificant relationship with financial performance and concludes that good credit management policy enhance financial performance of listed consumer goods companies in Nigeria.

In line with the findings of this study, it recommended that companies particularly the consumer goods companies should establish credit management policies that clearly outline the management's view of organization priorities on profitability. The credit policies should be continuously updated to reflect changes in the economic outlook of the customers to ascertain their adherence to payment.

\section{References}

Agu, O. C. \& Basil, C. O. (2013). Credit management and bad debt in Nigeria commercial Banks: Implication for development. Journal of Humanities and Social Science, 12(1), 47-56.

Akinleye, G.T., \& Olarewaju, O. O. (2019). Credit management and profitability growth in Nigerian manufacturing firms. $A U D O E, 15(2), 445-456$

Brigham, E. F., \& Houston, J.F. (2001). Essentials of Financial Management, (4th ed.), Singapore, Thompson Publishers.

Deloof, M. \& Jegers, M. (1996). Trade Credit, Product Quality and Intragroup trade: Some European evidence. Financial Management, 25(3), 33-43.

Dunn, M. (2009). Why you need a credit policy". Available online at http://www.entrepreneur.com/columnists/michelledunn/archive202424.html

Effiong, S.A., Akpan, E.I., \& Oti, P. A. (2012). Corporate governance, wealth creation and social responsibility accounting. Management Science and Engineering, 6(4), 110-114

Effiong, S.A., \& Ejabu, F.E. (2020). Liquidity Risk Management and Financial Performance: Are Consumer Goods Companies Involved? International Journal of Recent Technology and Engineering, 9(1), 580-589

Ifurueze M.S.K (2013). The impact of effective management on credit sales on profitability and liquidity of food and beverage industry in Nigeria. Global Journal of Management and Business Research USA 13(2), 14

Kalunda, E., Nduku, B. \& Kabiru, J. (2012). Pharmaceutical manufacturing companies in Kenya and their credit risk management practices, Research Journal of Finance and Accounting, 3(5), 159- 167

Kungu, J.N., Wanjau, K.L., \& Waititu, A.G. (2014). Effects of credit policy on profitability of manufacturing firms in Kenya. IOSR Journal of Economics and Finance, 2(4), 01-07

Long, M.S, Malitz, I. B., \& Ravid, S.A., (1993). Trade credit, quality guarantee and product marketability. Financial management, 22 (4), 117-127

Mbu-Ogar, G.B., Effiong, S.A., \& Abang, J. (2017). Corporate governance and organizational performance: evidence from the Nigerian manufacturing industry. Journal of Business and Management, $19(8), 46-51$

Muasya, M. (2013). The Relationship between Credit Risk Management Practices and Loans Losses. A Study on Commercial Banks in Kenya, Unpublished MBA Project, University of Nairobi.

Ojeka, S.A. (2012). Credit policy and its effects on liquidity: A study of selected manufacturing companies in Nigeria. The Journal of Commerce, 3(3), 10-19.

Okpala, K.E., Osanebi, C., \& Irinyemi, A. (2019). The impact of credit management strategies on liquidity and profitability. Journal of Behavioural Studies, 1(1), 1-11

Onuora, J.K. \& Ifeacho, S.N. (2017). The effects of credit management on profitability of manufacturing firm in Nigeria. Research Journal of Finance and Accounting, 8(10), 142-154.

Onuora, J. K., Nwafili, I. S. (2017). The effects of credit management on profitability of manufacturing firm in Nigeria. (A study of selected companies in Nigerian Stock Exchange). Research Journal of Finance and Accounting. 8(10), 142 - 154

Otuya, S. \& Akporien, F. (2017). Fraud risk management and sustainability of SMEs in Nigeria. 
International Journal of Innovative Research and Advanced Studies (IJIRAS), 4(8), 183-189.

Otuya, S. \& Eginiwin, E.J. (2017). Inventory management and SMES profitability. A study of furniture manufacturing, wholesale and eatery industry in Delta State, Nigeria. Journal of Finance and Accounting, 2017, 5(3), 75-79

Otuya, S. \& Ofeimun, G.O. (2017). Effects of board globalizing on financial performance of banks in Nigeria. International Journal of Academic Research in Accounting, Finance and Management Sciences. 7(4), 1-10.

Otuya, S. (2020). Inclusive financing and wealth redistribution: The role of microfinance banks in Nigeria. Economics and Social Sciences Academic Journal, 2(4), 10-20

Oyadonghan, K. J., \& Bingilar, P. F. (2014). The impact of effective credit policy on liquidity of manufacturing companies in Nigeria. European Journal of Accounting Auditing and Finance Research. 2(7), 88-100.

Pandy I.M. (2004). Financial Management. New Delhi, India: Vikas Publishing House.

Pandey, I. M. (2010). Financial management (10th ed.). New Delhi: Vikas Publishing House 